\title{
EDITORIAL
}

\section{In This Issue: Team-Based Care and Information to Improve Practice}

\author{
Kurt C. Stange, $M D, P b D$, Editor \\ Ann Fam Med 2014;2-3. doi: 10.1370/afm.1607.
}

$\mathrm{A}$ rticles in this issue of Annals enlighten development of effective primary health care teams and inform efforts to improve practice.

Relationships among members of the primary care team have been shown to be vital to the development of effective practices. ${ }^{1}$ Three studies in this issue examine work relationships and practice change in primary care practice.

Three different approaches for practice change are evaluated in a cluster randomized trial by Dickinson et al. ${ }^{2}$ The comparison of continuous quality improvement, reflective adaptive process, and self-direction for implementing the Chronic Care Model shows tradeoffs in improving diabetes quality measures and fostering practice and work culture change.

A qualitative study of small to midsized practices involved in a patient-centered medical home initiative examines strategies for engaging the entire practice in change efforts. The 13 identified strategies cluster into 3 themes that relate to effective internal communication, resource use, and creation of a team environment. ${ }^{3}$

A broad look at efforts to improve diabetes quality measures is taken by Peterson and colleagues ${ }^{4}$ in their evaluation of family physicians across the United States completing a diabetes Performance in Practice Module to meet recertification requirements of the American Board of Family Medicine. Among physicians completing nearly 8,000 modules, nearly one-half of all quality measures improved.

A cluster randomized trial of melanoma screening and education interventions finds improvements in patient knowledge, screening, and prevention behaviors. $^{5}$

A mixed methods study discovers practical opportunities for health behavior change for diet and physical activity. Using the Capability Framework and a community-based participatory approach, Ferrer and colleagues identify how the resources available in an economically disadvantaged community interact with personal circumstances to create capability or vulnerability. ${ }^{6}$
The utility of a single question about health to determine which patients are at risk for poor long-term depression outcomes is discovered by Ambresin and colleagues in a prospective study in 30 primary care practices. $^{7}$

In an article that adds to Ebell's recent study of patient expectations for antibiotic for a cough, ${ }^{8}$ Mustafa and colleagues ${ }^{9}$ use qualitative methods to find that practicing family physicians use indirect methods to explore expectations for treatment and their physical examination to build an argument for reassuring the patient or parent when antibiotics are not needed. These findings of the practices of experienced family physicians contrast with more academic communications literature and suggest that much might be learned from carefully examining the practices of those in real-world practice.

Systems thinking has tacitly and sometimes overtly influenced the thinking and action of primary care for decades. In a historical, integrative review, Sturmberg and colleagues describe the interrelated development of general practice/family medicine and understanding of complex adaptive systems theory. ${ }^{10}$

Annals Journal Club for this issue features the article by Mustafa and colleagues that explores ways to reduce inappropriate antibiotic prescribing by managing expectations. ${ }^{11}$

Finally, this issue publishes an archival manuscript from the (at the time) youngest generation of participants in the Keystone III conference that led to the Future of Family Medicine Project. ${ }^{12,13}$ Three editorials ${ }^{14-16}$ invite you to a conversation about what can be learned across generational differences.

We welcome your reflections at www.AnnFamMed. org.

\section{References}

1. Miller WL, Crabtree BF, Stange KC, Nutting PA, Jaén CR. Primary care practice development: a relationship-centered approach. Ann Fam Med. 2010;8(Suppl 1):S68-S79.

2. Dickinson WP, Dickinson LM, Nutting PA, et al. Practice facilitation to improve diabetes care in primary care: a report from the EPIC Randomized Clinical Trial. Ann Fam Med. 2014;12(1):8-16. 
3. Bleser WK, Miller-Day M, Naughton D, Bricker PL, Cronholm PF, Gabbay RA. Strategies for achieving whole-practice engagement and buy-in to the patient-centered medical home. Ann Fam Med. 2014;12(1):37-45.

4. Peterson LE, Blackburn BE, Puffer JC, Phillips RL Jr. Family physicians' quality interventions and performance improvement through the ABFM diabetes Performance in Practice Module. Ann Fam Med. 2014;12(1):17-20.

5. Rat C, Quereux G, Riviere C, et al. Targeted melanoma prevention intervention: a cluster randomized controlled trial. Ann Fam Med. 2014;12(1):21-28.

6. Ferrer RL, Cruz I, Burge S, Bayles B, Castilla MI. Measuring capability for healthy diet and physical activity. Ann Fam Med. 2014;12(1): 46-56.

7. Ambresin G, Chondros P, Dowrick C, Herrman H, Gunn JM. Selfrated health and long-term prognosis of depression. Ann Fam Med. 2014;12(1):57-65.

8. Ebell MH, Lundgren J, Youngpaoroj S. How long does a cough last? Comparing patients' expectations with data from a systematic review of the literature. Ann Fam Med. 2013;11(1):5-13.

9. Mustafa M, Wood F, Butler CC, Elwyn G. Managing expectations of antibiotics for upper respiratory tract infections: a qualitative study. Ann Fam Med. 2014;12(1):29-36.
10. Sturmberg JP, Martin C, Katerndahl DA. Systems and complexity thinking in the general practice literature: an integrative, historical narrative review. Ann Fam Med. 2014;12(1):66-74.

11. Annals Journal Club: Managing expectations for antibiotics when seeing patients with upper respiratory tract infections. Ann Fam Med. 2014;12(1)iii.

12. Generation III-Keystone III Working Group. A view from Cheyenne Mountain: Generation III's perspective of Keystone III. Ann Fam Med. 2014;12(1):75-78.

13. Martin JC, Avant RF, Bowman MA, et al; Future of Family Medicine Project Leadership Committee. The future of family medicine: a collaborative project of the family medicine community. Ann Fam Med. 2004;2(Suppl 1):S3-32.

14. Steiner E; for the Generation III-Keystone III Working Group. The changing world of family medicine: the new view from Cheyenne Mountain. Ann Fam Med. 2014;12(1):3-5.

15. Stange KS, Frey JJ III. Unresolved intergenerational issues. Ann Fam Med. 2014;12(1):5-6.

16. Rowland $\mathrm{K}$. The voice of the new generation of family physicians. Ann Fam Med. 2014;12(1):6-7.

\title{
EDITORIAL
}

\section{The Changing World of Family Medicine: The New View From Cheyenne Mountain}

\author{
Elizabeth Steiner, MDi for the Generation III-Keystone III Working Group \\ Ann Fam Med 2014;3-5. doi: 10.1370/afm.1621
}

E lectronic health records. Smart phones. Near-universal broad-band Internet access. Asynchronous communication. Electronic visits. Telemedicine. Patient-centered primary care homes (medical homes). Team-based care. A wide range of practice models. Hospitalists. Value-based purchasing. Accountable care. In the 13 years since the Keystone III conference that set the stage for the Future of Family Medicine (1.0) initiative, which attempted to renew and transform the discipline of family medicine, these innovations have all become commonplace, resulting in one of the most substantial transformations of primary care practice in the past century. The 10 members of the Generation III (youngest generation) group at the conference have been closely involved with many of these changes through practice, policy, research, and medical education $_{i}$ in many ways these changes represent a microcosm of the diversity among family physicians today.

As our original article makes clear, the definition of the "ideal" family physician was a recurrent theme during the Keystone conference. Those of us in Generation III, some late baby boomers and some early Gen Xers (those born 1964-1985), undoubtedly had expectations of work-life balance, the scope of our practices, and how we might structure our practices and careers that were different from those held by Generations I and II. Over the intervening years, it has become evident that one might best describe the ideal family physician as a pluripotent stem cell; our generalist inclination, diverse training, and range of meta-skills (listening, systems thinking, team-building, advocacy, etc) allow family physicians to pursue a wide range of careers both in and out of medicine, and even change

\section{CORRESPONDING AUTHOR}

Elizabeth Steiner, MD

Oregon Health \& Science University

3181 SW Sam Jackson Park Rd, Mail Code FM

Portland OR 97239

steinere@OHSU.edu 